\title{
Inching Away From the Barbarians
}

Journal of Research in Interprofessional

Practice and

Education

Vol. 3.1

Editorial

March, 2013

\section{Hassan Soubhi, MD, PhD}

Sociologist Talcott Parsons used the phrase "barbarian invasion" when he spoke of the birth of new generations of children [1]. I find a grain of truth in the phrase when I think of socializing new generations of healthcare students into their chosen professions. Acquiring the knowledge, attitudes, and values that would enable them to become functional members of their specific professional orders is a long, arduous, but necessary process - all the harder and all the more necessary when we try to socialize them into working with other professionals from different orders.

And doing so is unquestionable. For between the patient and the effective act of caring there has always been, and there will always be, a socialized group of assorted professionals-accepted and accepting members of society who fulfill the needed functions and roles of the group in solving the problems and riddles of illness.

I can see in the articles of this new issue of JRIPE a complex view of such a group and the process of enculturation that is required to develop it. Time is not the only requirement. Layered upon time are other ingredients like favourable attitudes toward interprofessional education [2], interprofessional support for patient safety [3], accepting others on one's own turf [4], understanding shared decision-making [5], enhancing students' formulation of multidisciplinary roles [6], involving patients in health professional education [7], improving buy-in and sustainability of integrated models of care [8], and developing strategies for assessing collaborative competencies [9].

None of these ingredients are context-independent-to say nothing of their being assembled here for the purpose of this editorial. Another set of accepted articles might have garnered a different set of ingredients. So no one-size-fits-all solution will ever be in view. Complex problems require multiple platforms from which to handle them. Enculturation of successive generations of students and professionals into interprofessional working will have to continue, inching forward, with a rigorous scientific enterprise to light the way. That is the price to pay for a situated, contextualized, and responsible participation in healthcare. And we would be all the wiser to expect more new questions than answers from any research worth its salt.

\section{References}

1. Parsons, Talcott. (1951). The social system. Glencoe, IL: Free Press.

2. Medves, J., Paterson, M., Broers, T., \& Hopman, W. (2013). The QUIPPED project: Students' attitudes toward integrating interprofessional education into the curriculum. Journal of Research in Interprofessional Practice and Education, 3(1), pp. 3-21.

3. Patterson, M., Medves, J., Dalgarno, N., O’Riordan, A., \& Grigg, R. (2013). The timely open communication for patient safety project. Journal of Research in Interprofessional Practice and Education, 3(1), pp. 22-42.

4. Kornelsen, J., Iglesias, S., Humber, N., Caron, N., \& Grzybowski, S. The experience of GP surgeons in western Canada: The influence of interprofessional relationships in training and practice. Journal of Research in Interprofessional Practice and Education, 3(1), pp. 43-61. 
2

Editorial

Hassan Soubhi
5. Dunn, S., Cragg, B., Graham, I.D., Medves, J., \& Gaboury, I. (2013). Interprofessional shared decision making in the NICU: A survey of an interprofessional healthcare team. Journal of Research in Interprofessional Practice and Education, 3(1), pp. 62-77.

6. Dalrymple, L., Hollins Martin, C., \& Smith, W. (2013). Improving understanding of teaching strategies perceived by interprofessional learning (IPL) lecturers to enhance students' formulation of multidisciplinary roles: An exploratory qualitative study. Journal of Research in Interprofessional Practice and Education, 3(1), pp. 78-91.

7. Doucet, S., Lauckner, H., \& Wells, S. (2013). Patients' messages as educators in an interprofessional health education program. Journal of Research in Interprofessional Practice and Education, 3(1), pp. 92-102.

8. Moore, A.E., Nair, K., Patterson, C., White, J., House, S., Kadhim-Saleh, A., \& Riva, J. Physician and nurse perspectives of an interprofessional and integrated primary care-based program for seniors. Journal of Research in Interprofessional Practice and Education, 3(1), pp. 103-121.

9. Murray-Davis, B., Solomon, P., Marshall, D., Malott, A., Mueller, A., Shaw, E., \& Dore, K. (2013). A team observed structured clinical encounter (TOSCE) for pre-licensure learners in maternity care: A short report on the development of an assessment tool for collaboration. Journal of Research in Interprofessional Practice and Education, 3(1), pp. 122-128. 